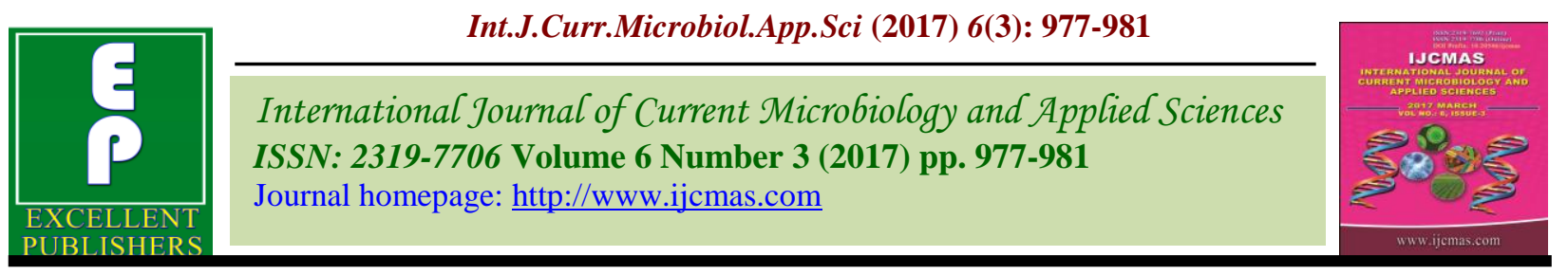

Original Research Article

https://doi.org/10.20546/ijcmas.2017.603.116

\title{
Root Traits and Its Correlation with Grain Yield of Rabi Sorghum Genotypes in Phule Root Box Structure under Receding Soil Moisture Condition
}

\author{
M.S. Shinde, V.R. A wari*, V.R. Patil, S.R. Gadakh, S.V. Nirmal, \\ U.S. Dalvi and L.V. Andhale \\ All India Sorghum Improvement Project, Mahatma Phule Krishi Vidyapeeth, \\ Rahuri 413722 (M.S.), India \\ *Corresponding author:
}

\begin{tabular}{|c|c|}
\hline & A B S T R A C T \\
\hline & Thirteen rabi sorghum genotypes were studied for root traits in rabi 2013-14 at All India \\
\hline Keywords & $\begin{array}{l}\text { Sorghum Improvement Project, Mahatma Phule Krishi Vidyapeeth, Rahuri in Phule Root } \\
\text { Box Structure under receding soil moisture. The genotypes were sown on exclusively }\end{array}$ \\
\hline $\begin{array}{l}\text { Drought, Root } \\
\text { traits, Extraction, } \\
\text { Moisture }\end{array}$ & $\begin{array}{l}\text { receding soil moisture under rainout shelter. The results of soil moisture status revealed } \\
\text { that the soil moisture gradually decreased from sowing till the harvest of crop. The } \\
\text { moisture depletion was less at vegetative phase as compared to reproductive phase. The }\end{array}$ \\
\hline Article Info & $\begin{array}{l}\text { sharp decrease with increasing depth was observed at reproductive phase. Root studies } \\
\text { revealed that the genotype RSV } 1410 \text { showed better root traits viz., root weight, number, }\end{array}$ \\
\hline $\begin{array}{l}\text { Accepted: } \\
18 \text { February } 2017 \\
\text { Available Online: } \\
10 \text { March } 2017\end{array}$ & $\begin{array}{l}\text { length and volume as compared to M } 35-1 \text {. Correlation studies indicate that root traits viz.; } \\
\text { root weight }\left(0.629^{*}\right) \text {, root number }\left(0.579^{*}\right) \text { and root length }\left(0.649^{*}\right) \text { showed significant } \\
\text { and positive correlation with grain yield Thus as per the objective of present investigation, } \\
\text { the rabi sorghum genotype RSV } 1410 \text { and Phule Anuradha were identified donor parent } \\
\text { which can be utilized in crop improvement programme especially for drought tolerance. }\end{array}$ \\
\hline
\end{tabular}

\section{Introduction}

The climate change may cause unpredictable draught. So it is necessary to have drought resistance in rabi sorghum genotype. Understanding the resistance mechanism and utilizing in breeding programme will be beneficial. Drought is one of the major constraints responsible for destabilizing the rabi productivity. The rabi sorghum is normally grown under stored and receding soil moisture. The limited availability of water cause moisture stress which affect to various metabolic processes of the plant. Root is important character for drought tolerance point of view. Genetic improvement of the plant for drought tolerance is a long term strategy and hence the root character studies assumes great importance. Therefore to generate the physiological information this aspects for breeding programme, the current innovation entitled "Root Traits and its correlation with Grain Yield of rabi sorghum genotypes in Phule Root Box Structure under receding soil moisture condition" was conducted during the 2013-14 at All India Coordinated Sorghum Improvement Project, MPKV, Rahuri.

\section{Materials and Methods}

A field experiment was conducted at All India Coordinated Sorghum Improvement Project, MPKV, Rahuri during rabi 2013-14 to study 
the root traits in Phule Root Box Structure under receding soil moisture condition. The experiment was conducted in Random Block design with two replications. The total thirteen rabi sorghum genotypes were studied. The gross and net plot size were $3.0 \times 0.90 \mathrm{~m}$ and 2.70 x $0.90 \mathrm{~m}$, respectively. Root study was done at maturity stage in Phule Root Box Structure method which a heap of entire soil profile was transferred on soil. The soil mass was pressed with heavy stone roller in order to maintain the soil density similar to natural condition. The 13 genotypes were sown on this heap. The sowing was done with 45 X 15 $\mathrm{cm}$ spacing. All recommended cultural and agronomic practices were followed to raise $\mathrm{s}$ good crop. The observations on root parameters viz.; root length, number of roots, root length, root volume and root ratio was recorded at harvest. For root observations five plants were randomly selected for each genotype. The number of effective plants bearing ear heads at harvest and earhead exertion percentage was computed. The grain yield per plant was recorded. At physiological maturity the total dry per plant was recorded. The harvest index was calculated by using the formulae as given by Donald (1962). The statistical analysis of data was carried out by Analysis of Variance method suggested by Panase and Sukhatme (1985). The correlation was worked out between grain yield and physiological parameters.

\section{Results and Discussion}

The rabi sorghum genotype were grown on exclusively receding soil moisture in rain out shelter. The soil moisture gradually decreased from sowing till the harvest of the crop (Table 1). The soil moisture was more at deeper depth under stress condition at physiological maturity. However a genotype possessing deep penetrating roots is more suitable under receding soil moisture. The results are in agreement with the findings of Nirmal and Patil (2008). The soil moisture depletion was less at vegetative phase as compared to reproductive phase. The sharp moisture percentage decrease with increasing depth was observed at reproductive phase. The difference in soil moisture extraction may be due to difference in genotypic rooting depth and density in the soil water potential to which root can extract water in canopy development and the stomata control of water loss. The increase in water use at reproductive phase as compared to vegetative phase cause due to increase in crop water demand during this phase to fulfill crop evapotranspiration for which root extracted more and more water from the all soil depth.

In the present investigation (Table 2) the genotype RSV 1410 (62 g), RSV 1098 (60 g) and Phule Anuradha (58 g) recorded higher root fresh weight under such receding soil moisture under rain out shelter condition. The root weight showed significant and positive correlation with grain yield $(0.629 *)$. Similar results have been reported by Nirmal et al., (2015). Higher number of roots helps to absorb larger quantity of water in the soil profile.

Table.1 Soil moisture status (\%) during crop growth period

\begin{tabular}{|l|l|l|l|l|}
\hline Sr. No. & Growth phases & \multicolumn{3}{l|}{ Soil Depth $(\mathrm{cm})$} \\
\cline { 3 - 5 } & & $0-30$ & $30-60$ & $60-90$ \\
\hline 1. & At sowing (\%) & 39.3 & 41.0 & 41.4 \\
\hline 2. & At panicle initiation (\%) & 38.7 & 40.3 & 40.6 \\
\hline 3. & At flowering (\%) & 31.9 & 35.8 & 38.0 \\
\hline 4. & At physiological maturity (\%) & 21.7 & 26.8 & 27.0 \\
\hline
\end{tabular}


Table.2 Root traits, grain yield, dry matter, earhead exertion and harvest index of rabi sorghum genotypes

\begin{tabular}{|c|c|c|c|c|c|c|c|c|c|c|}
\hline \multirow[t]{2}{*}{$\mathrm{SN}$} & \multirow[t]{2}{*}{ Genotypes } & \multicolumn{5}{|c|}{ Root Traits } & \multirow{2}{*}{$\begin{array}{l}\text { Earhed } \\
\text { exertion } \\
(\%)\end{array}$} & \multirow{2}{*}{$\begin{array}{l}\text { Total } \\
\text { Dry } \\
\text { matter } \\
\text { (g/pl. })\end{array}$} & \multirow{2}{*}{$\begin{array}{l}\text { Harvest } \\
\text { index } \\
(\%)\end{array}$} & \multirow{2}{*}{$\begin{array}{l}\text { Grain } \\
\text { yield } \\
\text { (g/pl.) }\end{array}$} \\
\hline & & $\begin{array}{l}\text { Fresh } \\
\text { root } \\
\text { weight } \\
\text { (g) }\end{array}$ & $\begin{array}{l}\text { No of } \\
\text { roots }\end{array}$ & \begin{tabular}{|l} 
Root \\
length \\
$(\mathrm{cm})$
\end{tabular} & $\begin{array}{l}\text { Root } \\
\text { Volume } \\
(\mathrm{m})\end{array}$ & $\begin{array}{l}\text { Root } \\
\text { shoot } \\
\text { ratio }\end{array}$ & & & & \\
\hline 1 & RSV 1098 & 60.0 & 49.0 & 76.5 & 64.0 & 0.34 & 84.5 & 218.5 & 22.3 & 51.0 \\
\hline 2 & MSV 71 & 49.0 & 33.5 & 71.5 & 57.5 & 0.40 & 83.3 & 201.0 & 10.8 & 40.5 \\
\hline 3 & RSV 1410 & 62.0 & 59.0 & 82.5 & 66.5 & 0.35 & 90.0 & 240.5 & 26.4 & 63.5 \\
\hline 4 & RSV 1429 & 52.0 & 34.0 & 61.5 & 47.5 & 0.34 & 80.5 & 207.5 & 24.1 & 50.0 \\
\hline 5 & CRS 15 & 56.0 & 39.0 & 63.5 & 63.0 & 0.37 & 83.0 & 212.5 & 15.7 & 33.5 \\
\hline 6 & CRS 19 & 49.0 & 46.5 & 82.0 & 61.5 & 0.47 & 81.0 & 228.5 & 22.6 & 51.5 \\
\hline 7 & BJV 83 & 41.0 & 37.0 & 66.5 & 57.5 & 0.38 & 88.5 & 206.0 & 15.2 & 31.5 \\
\hline 8 & BJV 103 & 50.5 & 46.0 & 64.8 & 52.5 & 0.33 & 81.5 & 201.0 & 19.4 & 39.0 \\
\hline 9 & CSV 19 SS & 56.5 & 49.5 & 53.5 & 37.5 & 0.27 & 84.5 & 216.5 & 15.7 & 34.0 \\
\hline 10 & Phule Chitra & 56.0 & 47.0 & 78.5 & 59.5 & 0.42 & 80.5 & 235.3 & 24.0 & 56.5 \\
\hline 11 & Phule Anuradha & 58.0 & 56.5 & 79.8 & 59.0 & 0.35 & 90.5 & 239.3 & 25.3 & 60.5 \\
\hline 12 & CSV 22 & 46.0 & 43.0 & 48.0 & 45.0 & 0.27 & 82.5 & 219.0 & 24.1 & 51.5 \\
\hline \multirow[t]{3}{*}{13} & M 35-1 & 47.5 & 44.5 & 60.0 & 52.5 & 0.31 & 81.0 & 217.5 & 25.2 & 55.5 \\
\hline & $\mathrm{SE} \pm$ & 3.3 & 2.2 & 3.1 & 4.1 & 0.02 & 2.5 & 3.6 & 1.4 & 3.0 \\
\hline & $\mathrm{CD}$ at $5 \%$ & 10.1 & 6.7 & 9.6 & 12.7 & 0.05 & 7.6 & 11.2 & 4.3 & 9.2 \\
\hline
\end{tabular}


Table.3 Correlation coefficient between grain yield and root traits, dry matter, earhead exertion and harvest index of rabi sorghum genotypes

\begin{tabular}{|l|l|l|}
\hline SN & Character & Correlation coefficient $(\mathrm{r})$ \\
\hline 1 & Root weight & $0.629^{*}$ \\
\hline 2 & No. of roots & $0.579 *$ \\
\hline 3 & Root length & $0.649^{*}$ \\
\hline 4 & Root volume & 0.439 \\
\hline 5 & Root shoot ratio & 0.431 \\
\hline 6 & Earhead exertion & $0.643^{*}$ \\
\hline 7 & Dry matter at harvest & $0.731^{*}$ \\
\hline 8 & Harvest Index & $0.667 *$ \\
\hline & *Significant at 5\% $\mathrm{r}=0.576$ at $5 \%$ \\
\hline
\end{tabular}

The genotype RSV 1410 recorded significantly higher mean number $\mathrm{f}$ roots (59) followed by Phule Anuradha (56). Due to higher number of roots of this genotype absorb large quantity of moisture and it resulted in the higher grain yield (63.5 and $60.5 \mathrm{~g} /$ plant), respectively. A positive and significant correlation $(0.579 *)$ with number of roots and grain yield was observed in the present investigation (Table 3). The above results are in agreement with the result reported by Nirmal and Patil (2008). Deep root length helps searching and absorption of water in the soil profile. The genotype RSV $1410(82.5 \mathrm{~cm})$ and Phule Anuradha (79.8 $\mathrm{cm})$ recorded significantly highest mean root length. The genotypes possessing deep penetrating root is more suitable for drought tolerance. A positive and significant association of root length $\left(0.649^{*}\right)$ with grain yield was observed. Similar results were also observed by Nirmal et al., (2015). The higher root volume was recorded in RSV 1410 (66.5 $\mathrm{ml})$ and RSV $1098(64.0 \mathrm{ml})$ among the genotypes studied. The higher shoot and root ratio under moisture regime was observed in the genotype CRS 19 (0.47) and Phule Chitra (0.42). Similar results in consonance with Nirmal et al., (2013).
The crop yield is an end product of various closely interlinked metabolic processes of the plants. In the present investigation the dry matter, earhead exertion percentage and harvest index showed significant difference among the genotypes. The earhead exertion (\%) expresses number of plants which bearing earhead under moisture stress condition. The genotypes RSV 1410 (90.0\%) and Phule Anuradha (90.5 \%) recorded the highest exertion percentage. A positive and significant correlation $\left(0.649^{*}\right)$ with grain yield was observed. These results in consonance with Nirmal and Patil (2008) and Nirmal et al., (2015). In the present studies, the genotypes RSV 1410 (63.5 g) and Phule Anuradha $(60 \mathrm{~g})$ produced significantly higher grain yield. This genotype possessed higher harvest index $(26.4 \%$ and $25.3 \%)$, respectively indicating efficient translocation of assimilates for grain yield. Thus the genotype also possessed higher dry matter (240.5g and $239.3 \mathrm{~g}$ respectively) since dry matter is highly associated with grain yield $(0.731 * *)$. A harvest index of RSV 1410 (26.4\%) and Phule Anuradha (25.3\%) were highest indicating efficient translocation of assimilates from source (stem) to grain (sink). Thus, it inferred that high yield of RSV 1410 
and Phule Anuradha was mainly due to higher root, weight, number, length, root shoot ratio, volume, dry matter and harvest index. Similar results were reported earlier by Kadam et al., (2002).

Thus as per the studies, the rabi sorghum genotypes RSV 1410 and Phule Anuradha were identified donor for drought tolerance which can utilized in rabi sorghum improvement programme. The key root traits viz.; Root weight, root length, number of root, root volume and root shoot ratio were identified for drought tolerance. These parameters could be considered while developing the variety suitable for drought tolerant.

\section{References}

Donald, C.M. 1962. In search of yield, $J$. Aust. Inst. Agric. Sci., 28(3): 171-178.

Kadam, G.N., Gadakh, S.R. and Awari V.R. 2002. Physiological analysis of rabi sorghum genotypes for shallow soil. $J$. of Maharashtra Agric. Univ., 27(3):
274-276.

Nirmal, S.V. and Patil, J.V. 2008. A new drought tolerant genotype SPV 1546 (Phule Suchitra). Ann. Pl. Physiol., 22: 165-168.

Nirmal, S.V., Dalvi, U.S. and Gadakh, S.R. 2013. Effect of water stress condition on root characteristics of sorghum plant under irrigated and rainfed condition. Crop Res., 45(1,2 \& 3): 132-135.

Nirmal, S.V., Gadakh, S.R., Bhoge, R.S., Dalvi, U.S. and Shinde, M.S. 2015. Evaluation of diverse genotype for rabi adaptation on medium soil. Nat. Academy of Agri. Sci., 33(1): 119-123.

Nirmal, S.V., Gadakh, S.R., Dalvi, U.S. and Shinde, M.S. 2015. Physiological characterization of rabi sorghum genotypes for drought tolerance under irrigated and rainfed condition, Indian J. Appl. Res., 5(4): 23-27.

Panse, V.G., and P.V. Sukhatme. 1985. Statistical Method for the Agricultural workers, ICAR, New Dheli, Publ., 2nd ed.

\section{How to cite this article:}

Shinde, M.S., V.R. Awari, V.R. Patil, S.R. Gadakh, S.V. Nirmal, U.S. Dalvi and Andhale, L.V. 2017. Root Traits and Its Correlation with Grain Yield of Rabi Sorghum Genotypes in Phule Root Box Structure under Receding Soil Moisture Condition. Int.J.Curr.Microbiol.App.Sci. 6(3): 977-981. doi: https://doi.org/10.20546/ijcmas.2017.603.116 